\title{
BULLETIN of the
}

\section{BUSINESS HISTORICAL SOCIETY}

PAST, PRESENT, AND FUTURE OF THE BUSINESS HISTORICAL SOCIETY

By N. S. B. Gras

LAND TITLE DIFFICULTIES IN MEXICO: A MEMORANDUM WRITTEN IN 1926

By William M. Ferris

THE ANNUAL REPORT AS A PUBLIC RELATIONS TOOL IN THREE INDUSTRIES

By Joe B. Frantz

RESEARCH IN PUBLIC ACCOUNTANCY

By Mary E. MurPhy

GENERAL MEETING OF THE MEMBERS OF THE BUSINESS HISTORICAL SOCIETY, INC. 


\section{BUSINESS HISTORICAL SOCIETY, INC.}

Organized in 1925 to promote the study

of business enterprise

from an historical point of view

Officers

Jorn W. Higgins, President

N. S. B. Gras, Vice-President

Aldan Forbes, Treasurer

Philip J. PotTer, Assistant Treasurer

Arthur H. Cole, Librarian

Thomas R. Navin

Executive Secretary and Clerk

Ersie H. BishoP

Assistant Executive Secretary
Members of the Council

Charles Francis adams Thomas C. Cochran Donatd K. David

Aluan Forbes

N. S. B. Gras

Charles B. Harding

JoHN W. HrgarNs

JoHN C. KHEXY

HenrietTa M. LaRson

Augustus P. Lorivg III

Henry L. Shattuck

D. George Sullivan

R. Gordon Wasson

Wallace B. Donham

Honorary Member

The Society collects business manuscripts, books, and reports, distributes publications, and otherwise promotes research; the Harvard Graduate School of Business Administration furnishes space and also assistance from the members of its faculty and staff. The Harvard Business School Associates receive all the publications of the Society.

\section{BULLETIN OF THE BUSINESS HISTORICAL SOCIETY, INC.}

HeNRIETta M. LARSON

Editor

ELsIr H. Bishop

Assistant Editor

Published quarterly and sent free to members of the Society.

For further information concerning the Society or the Bulletin, address The Business Historical Society, Soldiers Field, Boston 63, Massachusetts.

Copyright, 1950, by The Business Historical Society, Inc.

PRINTED IN D. 8. A.

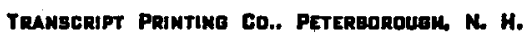

